\title{
UMCP-BG\&E COLLABORATION IN NUCLEAR POWER ENGINEERING IN THE FRAMEWORK OF DOE-UTILITY NUCLEAR POWER ENGINEERING EDUCATION MATCHING GRANT PROGRAM
}

\author{
Fiscal Year 2000 \\ - Status of Activities - \\ for \\ Baltimore Gas and Electric Company \\ Corporate Contribution and Community Relations Program \\ and \\ U.S. Department of Energy

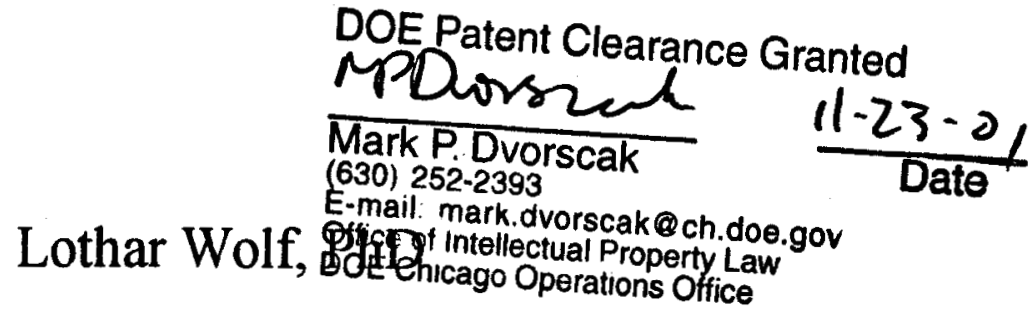

Nuclear Engineering Program

Department of Materials and Nuclear Engineering

G.L. Martin Institute of Technology

A.J. Clark School of Engineering

-University of Maryland College Park

College Park, MD

March 2000 


\section{DISCLAIMER}

This report was prepared as an aceount of work sponsored by an agency of the United States Government. Neither the United States Government nor any agency thereof, nor any of their employees, makes any wartanty, express or implied, or assumes any legal liability or responsibility for the accuracy, completeness, or usefulness of any information, apparatus, product, or process disclosed, or represents that its use would not infringe privately owned rights. Reference herein to any specific commercial product, process, or service by-trade name, trademark, manufacturer, or otherwise does not necessarily constitute or imply its endorsement, recommendation, or favoring by the United States Government or any ageacy thereof. The views and opinions of authors expressed herein do not necessarily state or reflect those of the United States Governmeat or any agency thereof. 


\section{DISCLAIMER}

Portions of this document may be illegible in electronic image products. Images are produced from the best available original document. 


\section{INTRODUCTION}

The DOE/Utility Nuclear Power Engineering Education Matching Grant Program has been established to support the education of students in Nuclear Engineering Programs to maintain a knowledgeable workforce in the United States in order to keep nuclear power as a viable component in a mix of energy sources for the country. The involvement of the utility industry ensures that this grant program satisfies the needs and requirements of local nuclear energy producers and at the same time establishes a strong linkage between education and day-to-day nuclear power generation.

As of 1997, seventeen pairs of university-utility partners existed. UMCP was never a member of that group of universities, but applied for the first time with a proposal to Baltimore Gas and Electric Company in January 1999 [1]. This proposal was generously granted by BG\&E $[2,3]$ in the form of a gift in the amount of $\$ 25,000$ from BG\&E's Corporate Contribution Program. Upon the arrival of a newly appointed Director of Administration in the Department of Materials and Nuclear Engineering, the BG\&E check was deposited into the University's Maryland Foundation Fund.

The receipt of the letter and the check enabled UMCP to apply for DOE's matching funds in the same amount by a proposal [4].

The Graduate School of UMCP, together with UMCP's Office of Research Administration and Advancement, had granted the request of waiving the overhead on DOE's matching funds for FY2000 in order to make optimal usage of the funds for educational purposes.

The cognizant project director was notified by the University's Office of Research Administration and Advancement (ORAA) by e-mail on September 28, 1999 about the arrival of DOE's matching funds in the amount of $\$ 25,000$. In waiting for DOE's matching funds contribution, no major expenditures were incurred for the BG\&E gift contribution, with the exception as noted below.

\section{Supported Activities}

\subsection{Educational Support}

As the major focus of the DOE-Utility Nuclear Power Engineering Education Matching Grant Program is the support of educational purposes, three undergraduate students were chosen to receive fellowships starting with the Spring term, paying their tuition (out-ofstate: one semester; in-state: two semesters) and textbook expenditures. The students selected are:

- Toni Chies

- Lisa Pollock

- Tamara Powell 
Their CVs are attached as Appendix A to this report. All three students have shown excellent commitment and dedication to nuclear engineering and constitute a wonderful spectrum of diversity - fully in line with the industry's and DOE's intention. Two of the students, Tamara Powell and Lisa Pollock have also applied for internships at Calvert Cliffs Nuclear Power Plant for this summer. Mr. Mathew Kattic of CCNPP's staff will follow up on these applications.

In addition, one graduate student, Marc Garland, has been chosen to receive a supplemental scholarship. His CV is also attached in Appendix A. Marc coordinated an Eagle Alliance congressional briefing on nuclear medicine in the Capitol on October 27, 1999. It dealt with the subject of nuclear medicine, presenting an overview of the discipline, prospects for future development, and impediments to that future development.

Given the success of that briefing and the need for support for future briefings, Marc has formed a University of Maryland chapter of the Eagle Alliance, an organization dedicated to reinvigorating nuclear science and technology. Our chapter will be responsible for coordinating the federal affairs of the organization. In particular, we will proceed with a series of congressional briefings that provide critical information to members of Congress and their staffs concerning issues vitally important to the future of nuclear science and technology.

A second briefing will be held in May to discuss the role of nuclear power in the United States' energy production strategy. Particular emphasis will be placed on the environmental aspects of nuclear power with respect to reduction of greenhouse gases, noxious gases, and particulates in accordance with the Kyoto Protocol and other environmental protection accords. The keynote speaker will be Denis Beller of the Los Alamos National Laboratory who was co-author of the article "The Need for Nuclear Power" in the January/February 2000 issue of Foreign Affairs. Also speaking will be Senator Pete Domenici (R-NM), a strong supporter of nuclear science and technology and Chairman of the Senate Appropriation's subcommittee on Energy and Water Development. Support for this briefing will also be provided by an alumnus of the Nuclear Engineering Program at the University of Maryland, Dr. Joseph Green, who is currently serving the first American Nuclear Society Glenn T. Seaborg Congressional Science and Engineering Fellowship in the office of Representative Joe Knollenberg (RMI), a majority member of the House Appropriations Committee's subcommittee on Energy and Water Development [5]. These subcommittees handle oversight and appropriations for the U.S. Nuclear Regulatory Commission and the Department of Energy.

Future sessions will cover the actions necessary to re-establish nuclear power plant manufacturing in the United States, disposal of high- and low-level wastes and the transportation of nuclear materials.

We believe that Marc Garland's mission and service for the nuclear power and engineering community is extremely helpful, warranted and important as he represents 
the young generation of the future which is welcome on the Hill. As such, that activity is fully in line with the industry's and DOE's intentions.

It is worth mentioning that all four students are American citizens.

All four students will be honored at an official large banquet by the UMCP Alumni Association in April. They will be called upon the stage with regards to the BG\&E/DOE Nuclear Power Engineering Education Matching Grant Program.

\subsection{Research Support}

With the DOE matching fund contribution focused only upon educational aspects, because of the mandatory requirements by the University's waiver on overhead, a fraction of the BG\&E gift has been earmarked for expenditures related to BG\&E's areas of interest.

The expenditures thus far encompassed the following:

a) Order of reports from NTIS, Springfield, in support of John Singleton's master thesis topic. John is a staff member at BG\&E's Calvert Cliffs Nuclear Power Plant. The reports cover steamline break analyses for Calvert Cliffs with different codes and were actually ordered on the one hand to shed some light on the corrupted mystery input deck for a RELAP5 analysis for CCNPP obtained from $B G \& E$ without any further information. In addition, they were ordered to replenish CCNPP's library as they cover aspects important to PTS analysis. Expenditures for that purpose were incurred primarily during the summer of 1999 when John Singleton started his MS thesis activities.

b) Three non-disclosure agreements with U.S. NRC to have full access to the latest versions of RELAP5 Mod 3.2.2, SNAP and XMGR5 to the students of the Nuclear Engineering Program and thus John Singleton. These agreements provided a special arrangement for John as being on the BG\&E staff and at the same time a student at UMCP.

c) John received training for the SNAP application at U.S. NRC.

d) He modeled and simulated a few pressurizer sample cases and is currently developing a steam-generator input model of CCNPP for RELAP5 as well as using the latést SNAP version to develop a RELAP5 model from TRAC-B model input for two selected THTF boil-off experiments [6] and to compare the RELAP5 computational results with those obtained from TRAC-B and TRAC-M [6]. The three topics: pressurizer, steam generator and THTF boil-off experiments encompass sufficient efforts to have John completing his MS thesis.

e) The only Postscript printer in the department's computer laboratory, connected to the DEC Alpha station of the Nuclear Engineering Program failed. Cost-sharing 
with the department incurred an expense of about $\$ 800$ for the BG\&E gift fund but provided a new HP printer. This printer was especially needed for John who has to operate RELAP5 at the DEC Alpha, rather than on his home computer.

f) A state-of-the-art report on worldwide progress in the area of pressurized thermal shock (PTS) was initiated and is about halfway complete. However, the highlights of mixing and flow analyses have not yet been incorporated as NRC did not finish the REMIX and FAVOR codes, thus far.

\subsection{Nuclear Engineering Program Support}

The reprinting of brochures covering Nuclear Engineering at UMCP will be paid ( $\$ 300)$ as no funds were available from the Department. These brochures will be given to about 100 high school students visiting the Nuclear Engineering Program's Radiation Facilities and Laboratories.

\section{Other Highlights}

Additional milestones reached over the reporting period were:

1) Successful ABET 2000 Review of the undergraduate curriculum of the Nuclear Engineering Program without any deficiencies. The official renewal of ABET accreditation is expected this summer.

2) The newly revamped graduate curriculum is being gradually phased in.

3) A number of new undergraduates have chosen to join Nuclear Engineering starting this Fall.

4) Dr. Gavrilas very successfully finished the advanced OECD/CSNI International Standard Problem on boric acid mixing simulation code verification.

5) Jason Floyd, a doctoral student of the Nuclear Engineering Program, made the renowned A-list of the National Research Council's Associateship Program with his fire research in nuclear power plant containments. He is the only applicant who made the A-list for the whole NIST organization in Gaithersburg. This is very surprising given the heavy competition.

4. Summary

The activities funded by the BG\&E/DOE gift and matching funds constitute a financial commitment of about $45 \%$ of the total of available funds through the end of the summer 2000. We believe that we were able to move a number of issues in the right direction, foremost to start stabilizing the undergraduate student program as well as supporting important issues of interest to industry and DOE in the graduate student program, while still maintaining a tight grip on financial spending. The rest of the money is planned to 
cover uncertainties as regards to graduate student research projects over the summer. The available money provides coverage for anticipated emergencies given the circumstances.

References

[1] Wolf, L.: UMCP-BG\&E Collaboration in Nuclear Power Engineering in the Framework of DOE-Utility Nuclear Power Engineering Education Matching Grant Program, Proposal to BG\&E, Jan. 1999

[2] Lockhart, C.D.: Letter to L. Wolf with check in the amount of $\$ 25,000$, dated February 22, 1999

[3] Cruse, C.H.: Letter to L. Wolf, dated February 24, 1999

[4] UMCP: UMCP-BG\&E Collaboration in Nuclear Power Engineering, Proposal to U.S. DOE, March 18, 1999

[5] ANS News: Title Story: First ANS Congressional Fellow at Work in U.S. Congressman's Office, January/February 2000

[6] Rauch, B., et al: Task Order No. 9: BWR Model Development and Assessment, Contract NRC-04-97-046: Task 1: TRAC-M Calculations for the THTF Boil-Off Tests, Nuclear Engineering Program, Department of Materials and Nuclear Engineering, University of Maryland College Park, UMCP-TRAC-M 01, Feb. 2000 


\section{APPENDIX A}

\section{CURRICULUM VITAE OF SUPPORTED STUDENTS}




\section{Toni A. Chies}

12 Woodland Ct., Apt. 101

Telephone: (301) 362-0325

Laurel, MD 20707

Email: tonich@glue.umd.edu

Education

University of Maryland at College Park: B.S., Nuclear Engineering expected May 2001. Minor in Chemical Engineering. GPA: 3.1/4.0.

A.A, Anne Arundel Community College, 1998.

Job Experience

1998-present Research Assistant, Department of Materials and Nuclear Engineering, University of Maryland at College Park

- Operated $9.5 \mathrm{kCi}{ }^{\infty} \mathrm{Co}$ Gamma Irradiator Cell

- Experience with 2-9.5 MeV Electron Accelerator (LINAC)

- Attended several Re-qual meetings

- Calibration Tectnician for Dosimetry Lab

- Trained co-workers on Gamma Cell

- Researched the Degradation of Polychlorinated-biphenyls using Irradiation

- Assisted in the coordination of a NSF workshop hosted by the University

1998-1999 Math Laboratory Technician, Math Department, Anne Arundel Community College assisting classes with computer math programs and tutoring students one-on-one in college math.

\section{Achievements and Awards}

2000

1999

1998

1997

1996
Department of Materials and Nuclear Engineering Scholarship American Nuclear Society Scholarship Women In Engineering Research Fellowship Radiation Protection Training Course Certificate HOPE Scholarship (for outstanding academic performance and helping peers)

\section{Activities}

American Nuclear Society

American Institute of Chemical Engineers

Best Buddies (volunteer organization)

Circle K (volunteer organization) 


\section{References}

Dr. Mohamad Al-Sheikhly, Director of Radiation Facilities, University of Maryland, Department of Materials and Nuclear Engineering, (301) 405-5214.

Dr. Joseph Silverman, Professor Emeritus, University of Maryland, Department of Materials and Nuclear Engineering, (301) 405-5228.

Mr. Vincent Adams, Assistant Director of Radiation Facilities, University of Maryland, Department of Materials and Nuclear Engineering, (301) 405-5230. 


\title{
Tamara Dawn Powell
}

\author{
1923 Columbia Avenue \\ Landover, MD 20785 \\ (301) 322-3674 \\ tamarap@wam.umd.edu
}

\section{OBJECTIVE}

EDUCATION
To obtain a position in an environment offering challenge and growth.

University of Maryland at College Park

A. James Clark School of Engineering

B.S. Degree in Nuclear Engineering expected May 2001

Related Coursework:

-Introduction to Engineering Design

-Nuclear Reactor Engineering I
-Introduction to Nuclear Technology

-Nuclear Engineering Laboratory I

\section{RELEVANT EXPERIENCE}

June 1998-August 1998;

Dec.1998-January 1999;

- June 1999-August 1999

April 1998-May 1999;

May 1997-April 1998

May 1997- May 1998

COMPUTER SKILLS

HONORS

\section{ORGANIZATIONS \\ 1999-present}

1995-present

1995-1997

\section{PECO Energy Company}

Technical College Intern in Thermal Performance Monitoring and Fuels and Services; Put an efficiency loss model for leaking valves in place which required learning to work with state-of-the-art beta software; Created a MS Access database for frequently referenced documents which enabled users to search through hundreds of documents by subject matter, Eamed an overall rating of "superior" upon final evaluation by supervisors; Gained experience working in an office environment

University of Maryland, Black Engineers Society

Chapter Vice-President 1998-99; Chapter Treasurer 1997-98; Planned chapter events; Coordinated Big/Little Program; Served as Chairperson for the M.L. Cherry Scholarship Committee; Fufilled presidential duties in the absence of the president; Member of Pre-College Initiative and Awards Banquet Committees; Facilitated general body meetings; Managed and distributed funds; Created and maintained budget; "Big Sister" for Big/ Little Program; Tutored students in Saturday Tutoring Program; Gained valuable leadership experience

University of Maryland, Institute for Physical Science Technology and Department of Chemical Engineering

Undergraduate Research Assistant with Dr. Michael T. Harris in the fields of Colloid Science, Surface Science and Reaction Engineering; Gained knowledge in measurement of particle size, zeta potential, and mobility with Dynamic Electron Light Scattering Apparatus (DELSA)

Software- FORTRAN, HTML, Mathcad, MATLAB, Microsoft Access, Microsoft Excel, Microsoft Word, PASCAL, WordPerfect

Operating Systems- DOS, IBM PC and compatible, Macintosh, Windows 98

National Scjence Foundation AMP (Alliance for Minority Participation) Scholar

University of Maryland President's Scholar

University of Maryland Honors Program

BRIDGE Program for Freshman Engineers

\section{American Nuclear Society}

Chapter Secretary

National Society of Black Engineers (NSBE)

1998 Region II Fall Conference Planning Committee, Entertainment Chair

University of Maryland Gospel Choir 
HIGHLIGHTS - Programming in FORTRAN, MATLAB, and Excel

- Statistical analyses of data sets

- Radiation detection and measurement

- Strong writing skills

OBJECTIVE A summer internship in the chemical or nuclear engineering field.

\section{EDUCATION}

University of Maryland

College Park, MD

B.S. nuclear engineering, with secondary field in chemical engineering 2001

- Earned a 3.0 grade point average

\section{EXPERIENCE}

Department of Materials and Nuclear Engineering Undergraduate research assistant
College Park, MD September 1999 to present

- Identified, categorized, documented and assessed experimental data sets for Boiling Water Reactor Model Development and Assessment

Campus Recreation Services

Instructor

- Instruct children and adults in swimming and lifeguarding

Department of Materials and Nuclear Engineering

College Park, MD Undergraduate fellow for the UM 2X4 Loop Facility September 1998 to May 1999 - Performed statistical analyses on large experimental data sets

Colorado School of Mines Summer Intern

- Carried out research in artificial intelligence and robotics

\section{CAMPUS INVOLVEMENT}

- Served as president of the University of Maryland student chapter of the American Nuclear Society, January 1999 to present

- Student Manager of the University of Maryland swim team

- Citation in College Park Scholars program in Science, Technology and Society

\section{REFERENCES}

Will be furnished on request. 


\section{OBJECTIVE}

I am currently working on Master's and PhD Degrees in Nuclear Engineering at the University of Maryland. My areas of interest are in nuclear reactor technology, isotope production, and medical applications of radioisotopes. I will complete the Master's Degree requirements in the Fall 1999 semester.

\section{EXPERIENCE}

PACIFIC NORTHWEST NATIONAL LABORATORY

HANFORD RADIOISOTOPES PROGRAM

Nuclear Engineering Fellow, 5/99 - Present

Perform calculations for the production of radioisotopes in the Fast Flux Test Facility at Hanford and the High Flux Isotope Reactor at Oak Ridge.

\section{UNIVERSITY OF MARYLAND}

\section{CENTER FOR MICROANAL YSIS}

Graduate Assistant (Part-Time), 1/98 - 1/99

Operate various electron microscopes for students and corporate customers and provide training on the use of electron microscopy equipment. Served as acting manager of the facility 10/98 - 1/99 after the departure of the facility director.

\section{NATIONAL INSTITUTE OF STANDARDS AND TECHNOLOGY CENTER FOR NEUTRON RESEARCH \\ Engineer Trainee (Part-Time), 7/98 - 9/98}

Assist in the design, development, implementation, and testing of electronics for the Cold Neutron Beam Time-of-Flight Disk Chopper System. This includes voltage distribution and monitoring circuit boards and data collection circuits which incorporate PLD technology.

B\&W HANFORD COMPANY/WESTINGHOUSE HANFORD COMPANY

FAST FLUX TEST FACILITY TRANSITION PROJECT OfFICE

Senior Plant Engineer (Part-Time), 1/95 - 1/98

Coordinate long-range planning and scheduling and develop innovative, cost-effective strategies to perform FFTF transition and restart activities.

WESTINGHOUSE HANFORD COMPANY

Plutonium Finishing Plant Work Control Center

Manager. 8/93 - +1/95

Manage the PFP; Work Control System to ensure work is performed in accordance with company policies and DOE Orders. Develop and implement a system for reeall of periodic maintenance and Operational Safety Requirement Surveillance activities.

WESTINGHOUSE HANFORD COMPANY

HANFORD WASTE VITRIFCATION PLANT

Senior Plant Engineer, 3/93 - $8 / 93$

Develop Operations programs for the HWVP project. Initiate planning for creating a Work Control/Scheduling Integration organization. Control the integrated schedule for HWVP plant startup activities. 
WeStinghouse HANFord COMPANY/Westinghouse SAVANNAH RIVER COMPANY

DEFENSE WASTE PROCESSING FACILITY OPERATIONAL READINESS REVIEW

Senior Plant Engineer, 4/92 - 3/93 (Temporary Assignment)

Conduct Operational Readiness Reviews of the Defense Waste Processing Facility (waste vitrification plant) at Savannah River (led the assessment of the Melter and Off-Gas Systems and participated in the assessment of Quality Assurance).

WESTINGHOUSE HANFORD COMPANY

FFTF REFUELING AND MAINTENANCE PLANNING

Lead Engineer, $9 / 88$ - 4/92

As Lead Engineer in Work Control, define work scope for reactor outages and operating cycles, assign priorities to work documents, approve facility modifications and test procedures, and implement the Work Control System to ensure work is performed in accordance with company policies and DOE Orders.

\section{WESTINGHOUSE HANFORD COMPANY}

FFTF OPERATIONS/FFTF TRAINING

Senior Plant Engineer, 11/79 - 9/88

As a qualified Reactor Operator/Operations Engineer, direct safe operation of FFTF and administer the work control program.

As a Training Engineer, coordinate the Reactor Technician/Operations Engineer Training, FFTF Plant Drill, and Operator Training Manual programs. Develop and present classes to support various operator academic programs; in particular, reactor control systems and physics.

\section{EDUCATION}

UNIVERSITY OF WASHINGTON

BS, Biology 1979

WASHINGTON STATE UNIVERSITY - TRI-CITIES

MS, Electrical Engineering 1998 (4.00 GPA)

UNIVERSITY OF MARYLAND

MS. Nuclear Engineering 1999 (planned completion) (4.00 GPA)

\section{HONORS AND AWARDS}

DEPARTMENT OF ENERGY

Nuclear Engineering Fellowship, 1/99 - Present

SCHOLARSHIPS:

AMERICAN NUCLEAR SOCIETY, EASTERN WASHINGTON SECTION, 1998

INSTRUMENT SOCIETY OF AMERICA, 1997

INSTITUTE OF INDUSTRLAL ENGINEERS, 1997

\section{TECHNICAL/PROFESSIONAL ORGANIZATIONS}

Nuclear Medicine Research CoUnCIL (PASt-PREsident)

1 have been an active member of the NMRC since November 1996 and was elected President in February 1997. My contributions to the organization have been:

In response to criticism of FFTF restar by organizations such as Heart of America Northwest and Physicians for Social Responsibility, I wrote a letter to Secretary of Energy Hazel O'Leary on behalf of 
the medical and scientific communities supporting FFTF restart for the production of medical isotopes. I got the endorsement of 69 medical and scientific experts (including Nobel Prize winner Glenn Seaborg) and sent the letter to the Secretary December 10, 1996. Since then it has been reported that the letter has been used by the Washington State congressional delegation and Tri-Cities officials to influence their peers and Northwest organizations in support of a medical isotope production mission for FFTF.

Prior to Secretary O'Leary's anticipated late-December 1996 decision on the future of FFTF, I organized a public information forum on medical isotope production at FFTF to emphasize the importance of FFTF restart and to display community support for an FFTF medical isotope mission. The forum included presentations on nuclear medicine, isotope production in the United States and FFTF production capabilities, and the economic, environimental, and public policy impacts of FFTF operation. Representatives of members of the Washington State Legislature and the United States Congress attended and the forum was broadcast on local cable.

An initiative to use federal funds (Section 3161 of the 1993 Defense Appropriations Act) for the production of a strategic plan to stimulate development of a nuclear medicine industry in the Tri-Cities was in jeopardy of being dismissed by the Tri-Cities Industrial Development Council (TRIDEC, the administrators of 3161 funds) as the NMRC had failed to meet deadlines for submittal of required information. I took over coordination of the project April 1, 1997, resolved our relationship with TRIDEC and signed a $\$ 30,000$ contract on May 16, 1997.

I played leading roles in organizing a conference, "Future Role of FFTF as a Supplier of Diagnostic and Therapeutic Medical Isotopes" attended by some of the most prominent physicians in the field of nuclear medicine and a symposium for the physicians and the general public, "Accelerating Nuclear Medicine Techniques and Treatments," both of which were successfully conducted in September 1997.

As President, I transformed the NMRC from an information sharing organization to a group that actively promotes the development of nuclear medicine. To do this, I organized three committees: an Outreach Committee to produce informational materials (brochures and pamphlets), develop material for our internet home page, and coordinate letter writing campaigns; a Finance Committee to write grant proposals for nuclear medicine research and applications in the Tri-Cities and to raise money for other NMRC activities; and an Advisory Group Committee to form an advocacy group of nationally recognized experts in nuclear medicine that would inform the public, Congress, and other governmental agencies of the importance of radioisotopes in medicine and the capabilities of FFTF in supplying medical isotopes.

\section{AMERICAN NUCLEAR SOCIETY}

I am a member of the national society and the Washington, DC, Eastern Washington, and University of Maryland sections. I was an active member of the Eastern Washington ANS chapter's Public Information Committee which disseminates nuclear issue-related information to the general public.

\section{Eagle AllLance}

I am currently coordinating a Congressional briefing on nuclear medicine to be held in the Capitol on October 27, 1999. The briefing will be conducted by the President-Elect and a Past-President of the Society of Nuclear Medicine and a Past-President of the American Nuclear Society.

AMERICAN ASSOCLATION FOR THE ADVANCEMENT OF SCIENCE INSTITUTE OF ELECTRICAL AND ELECTRONICS ENGNEERS SOCIETY OF NUCLEAR MEDICINE 


\section{POSITIVE ADULT LEADERS}

I tutor disadvantaged and under-performing children through a program at the Kingman Boys and Girls Club in Washington, DC.

\section{TEMPLE MICAH}

I am a volunteer at Temple Micah Synagogue in Washington, DC where I help administer financial programs.

\section{OREGON STATE UNIVERSITY/WASHINGTON STATE UNIVERSITY TRI-CITIES}

The Tri-Cities (located in eastern Washington state) no longer has degree programs available in nuclear engineering. Advanced degree programs could attract nuclear engineers to reconstitute the FFTF technical staff that has diminished significantly since the reactor was shut down. These programs could also enhance the development of nuclear medicine-related activities in the Tri-Cities. I investigated the options for re-establishing nuclear engineering advanced degree programs and found that a joint effort involving Oregon State University and Washington State University Tri-Cities could be successful. Working with representatives of OSU, WSU-TC, the Pacific Northwest National Laboratory, Hanford PHMC Contractors, Siemens Nuclear Power Corporation, and the Washington Public Power Supply System, I organized meetings to discuss the universities' and companies' interest in these programs and developed a survey of student interest that was conducted by PNNL and OSU. Sufficient interest was demonstrated by prospective students and local companies and OSU and WSU-TC are now formulating plans to offer nuclear engineering and radiation health physics advanced degree programs in the Tri-Cities.

\section{UNITED WAY}

I was a volunteer for the annual Benton-Franklin County United Way fundraising campaign in eastern Washington state.

\section{CONGREGATION BETH SHOLOM}

I served four years as treasurer and two years as vice-president of Congregation Beth Sholom Synagogue in Richland, WA. 


\section{APPENDIX B}

\section{BG\&E's NEWS RELEASE}




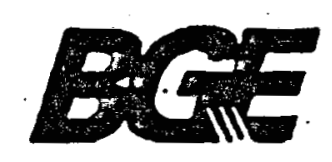

Public Information Office

$$
=
$$

\section{$\mathrm{New} \mathrm{s}$ \\ $\mathrm{R}$ ele as e}

Battimoro Gas and Electric

Company

39 W. Loxington Stroot

Room 1100

Baltimore. Manyland 21201

410234743324 hours a didy

Contact. David Austin

410-495-6740

\section{BGE GIFT TO UNIV. OF MD: \\ A POWERFUL PARTNERSIIP FOR A BRIGHT FUTURE}

Baltimure, April 20, 1999 - With an eye toward meeting the growing demand for electrical power w 'hile preserving the nation's natural resources, Baltimore Gas and Electric (BGE) recently donated \$25,000 to the University of Maryland's Nuclear Engineering Program. The gift will helig support students, computer and nuclear engineering facilities. The contribution will be matcher, dollar-for-dollar, by the Department of Energy's (DOE) Urility Matching Grant Progrint.

"We are especially pleased about this gift because it will help the University of Misyland to concinue very important work - training the next generation of nuclear eagineers, "said Charles H. Cruse, BGE Vice President, Nuclear Enerey Division. "Their work will help provide this region - and indeed this nation - with the power it needs to meet the challenges of the next millesnium. We're excited about their work and their future."

Wath

"BGE and the University of Maryland have a strong working relationship," said Locthar Wolf, Lniversity of Maryland Professor, Department of Materials and Nuclear Engineering. "It's fet one whese classroom theory meets practical application, resulting in an enriching and

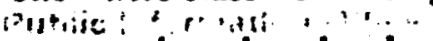
empowuring educational experience and successful, professional joint ventures." 
$\therefore$. "The University has provided us with technical expertise and support on a number of key projects including the development of models for a thermal hydraulics code which augments our safety analysis," said Mr. Cruse. "In addition, many UM graduates have become valuable additions to our staff here at Calver Cliffs Nuclear Power Plant. We have more than 400 employees throughout BGE who are setively enrolled or have graduated from the University of Maryland system."

. .. Salvert Cliffs is a two-unit generating station, located in Calvert County on the westem shore of the Chesapeake Bay. Last year, Calvert Cliffs generated mare than 40 percent of a I the electriciiy used by BGE's 1.1 million electric customers.

iif

$\therefore$

\section{\#\#}

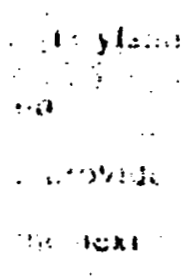

in: :

m?!? 


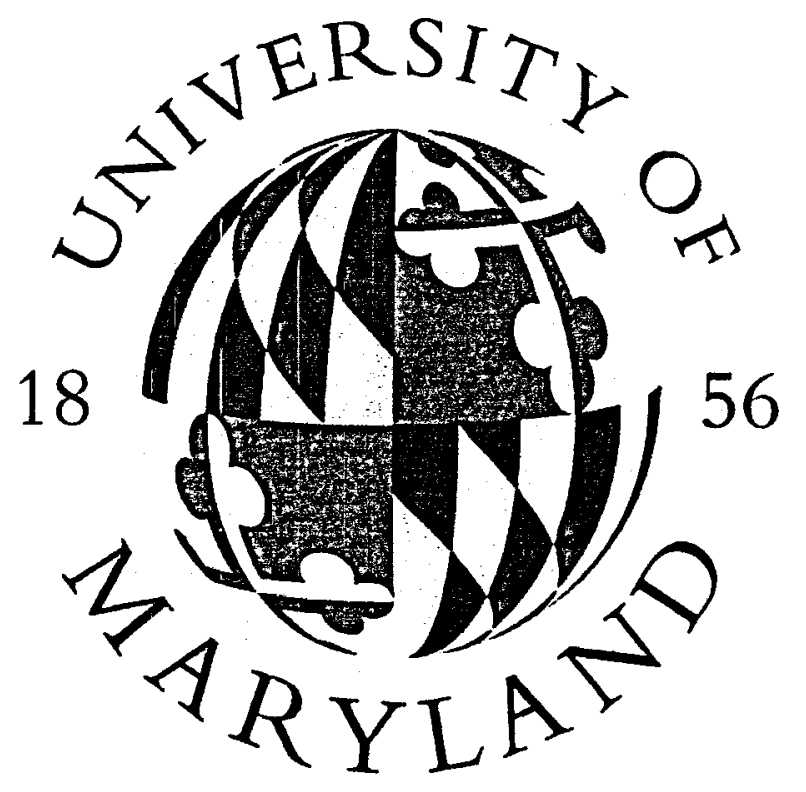

NUCLEAR ENGINEERING PROGRAM AND CENTER FOR TECHNOLOGY RISK STUDIES

IN DEPARTMENT OF MATERIALS AND NUCLEAR ENGINEERING

G.L. Martin Institute of Technology

A.J. Clark School of Engineering

UNIVERSITY OF MARYLAND

College Park, MD

October 2000 


\section{TABLE OF CONTENTS}

NUCLEAR ENGINEERING PROGRAM AT THE UNIVERSITY OF MARYLAND

1. Introduction

2. Undergraduate Student Curriculum in Nuclear Engineering 2

2.1 Mission Statement 2

2.2 Constituencies and Evaluation/Review of Educational Objectives 3

2.3 Program Outcomes 3

2.4 Curriculum 4

2.4.1 Mathematics and Sciences 4

2.4.2 Engineering Topics 6

2.4.3 General Education 9

3. Graduate Student Curriculum in Nuclear Engineering 10

4. Professional Masters of Engineering 10

5. Professional Courses 11

6. Role of Research in Curricula 11

7. Faculty 11

\section{CENTER FOR TECHNOLOGY RISK STUDIES (CTRS)}

1. Objectives 13

2. Rationale for the Center 13

3. Organization 14

4. Facilities 14

5. Sponsors 15

6. Accomplishments 15

7. Recent Activities 15

8. Contact Information 16 


\section{NUCLEAR ENGINEERING PROGRAM AT THE UNIVERSITY OF MARYLAND}

\section{Introduction}

The Nuclear Engineering Program is one of a total of three programs constituting the Department of Materials and Nuclear Engineering in the A.J. Clark School of Engineering at the University of Maryland College Park. The other two programs are Materials Science and Engineering and Reliability and Risk, respectively.

The Nuclear Engineering Program has maintained a fully ABET-accredited undergraduate curriculum in nuclear engineering and offers a graduate curriculum leading to the M.S. and Ph.D. degrees.

Beyond the standard university courses, the Nuclear Engineering Program, has also developed a number of professional courses offered to industry and the federal government at the campus or on-site of the interested party.

As the Nuclear Engineering Program, the Department and the University strive to provide optimal ways for continued education and life-long learning a number of options have been devised. Currently, a Professional Master of Engineering degree for the practicing engineer (professional master) is being offered. Also, a Certificate Program exists and others such as a Credential Program are being discussed.

The Nuclear Engineering Program at $\mathrm{UM}$ is among a few remaining programs in the nation that offer the full spectrum of:

a) an operational university research and training reactor (MUTR $250 \mathrm{~kW}$ )

b) a $10 \mathrm{kCi}$ Cobalt-60 source

c) radiation measurement laboratories

d) University of Maryland $2 \times 4$ thermal-hydraulic loop

e) special materials examination and testing laboratories operated by the Materials Science and Engineering Program

Brief summaries of the main characteristics of these facilities are provided in the Appendix.

With the features listed above, the Nuclear Engineering Program is the only one of its kind in the State of Maryland providing teaching and research in the areas of radiation sciences and engineering, nuclear power engineering, safety, plant operation, reliability and risk. 


\section{UNDERGRADUATE STUDENT CURRICULUM IN NUCLEAR ENGINEERING}

\subsection{Mission Statement}

The mission of the undergraduate Nuclear Engineering Program of the Department of Materials and nuclear engineering at the University of Maryland is to provide a quality engineering education that has sufficient breadth to include training in both fundamental and specialized engineering topics in order that the graduates meet the current and future needs to society. Additionally, the mission of the Department is to conduct a range of research programs, establish partnerships with government organizations and private industry, both in Maryland and elsewhere, and to provide service to the overall campus community.

Nuclear and radiation engineering combines fundamental science with the most advanced technologies available today. The educational goals of the program are to provide an undergraduate curriculum which equips the graduate with the necessary skills to meet the challenges of the future. The degree provides students with the following essential elements: a firm grasp of the fundamentals of science and engineering, ample exposure to a wide range of applications, and an understanding of contemporary issues and the need for lifelong learning.

The undergraduate Nuclear Engineering degree program provides the student with a strong engineering education that has a solid emphasis on the application of nuclear and radiation engineering to a wide variety of engineering fields. An important component of the overall degree program is the requirement that the student select a secondary engineering field, which consists of a minimum of four upper level (junior/senior) courses in another engineering discipline taught in the Clark School of Engineering.

The overall educational objectives of the Nuclear Engineering program are to provide undergraduate engineering students with:

1. a quality education which will produce graduates who are highly skilled in engineering and who have the tools to continue learning throughout their careers.

2. an understanding of the fundamentals of nuclear and atomic physics and engineering sciences

3. an understanding of the fundamentals of radiation transport and interactions

4. the capabilities to apply these knowledge in the following areas:

a. radiation engineering

b. reactor physics and neutronics

c. nuclear system thermalhydraulics and safety

5. an enhancement of nuclear and radiation engineering topics by appropriate selection of secondary engineering field courses

6. the skills to design applications for technologies utilizing nuclear and radiation systems for a specific end use 
7. the skills to work as a nuclear and radiation engineering specialist in a professional setting

8. the necessary skills to pursue a graduate engineering degree at the top programs in the country

The Nuclear Engineering curriculum enables the student to meet these program educational goals by providing:

1. a solid foundation in mathematics, physics, chemistry, and basic engineering sciences

2. an integrated program of required nuclear engineering courses that cover both fundamental and applied topics

3. a choice of the secondary engineering field, which provides the students with in-depth knowledge in a second engineering discipline which couples with nuclear and radiation technologies

4. a choice of additional technical and engineering electives to further enhance the areas of interest of the individual student

5. opportunities for students to work with faculty and industry on complex engineering problems through projects, internships, jobs, and co-operative experiences

6. a senior design project which brings together the many aspects of nuclear end radiation engineering in a global context that prepares the student to function as a practicing engineer

7. Mandatory semester advising and planning of individually tailored educational and career goals for the student

\subsection{Constituencies and Evaluation/Review of Educational Objectives}

The significant constituencies of the Nuclear Engineering Program are the students, faculty, Clark School of Engineering, University, and industry (private and government). On-going methods that are used to evaluate the educational objectives include:

1. a biannual presentation to the Department Board of Visitors, which includes both nuclear and radiation professionals as well as materials professionals

2. graduate exit surveys and alumni surveys administered by the School of Engineering

3. graduate exit interviews administered by the Department

4. internships and summer jobs opportunities

5. teaching and course content evaluations

6. mandatory advising for all students each semester

7. ongoing program review by faculty.

\subsection{Program Outcomes}

The Nuclear Engineering Program has established the following Program Outcomes based on the Program Educational Objectives.

The Nuclear Engineering Program requires graduates to demonstrate that they have the ability to: 
1. apply the fundamental and applied principles of mathematics, physics, chemistry engineering sciences, and nuclear and radiation engineering to solve problems of interest to industry and society

2. design and conduct experiments which measure radiation processes, apply appropriate mathematical models to analyze the data, interpret the data, and present results as a technical paper and/or oral presentation

3. apply design processes to a system or process to solve a specific design problem in nuclear and radiation engineering

4. function on teams

5. understand contemporary issues and how engineering impacts society

6. speak and write effectively

7. obtain entry level engineering position in his/her area of interest, and/or continue on to graduate education

8. have the necessary abilities to engage in learning throughout their professional careers

\subsection{Curriculum}

The curriculum of the Nuclear Engineering Program is designed to provide the student with course work that meets the overall Program Educational Objectives. A student who graduates from the program is, therefore, prepared to enter the professional work force as a practicing engineer.

- The Professional Component of the curriculum consists of three major segments: (1) basic mathematics and sciences; (2) engineering topics; and (3) general education. Each of these is described in detail below. The undergraduate semester by semester curriculum is shown in Table 1.

\subsubsection{Mathematics and Sciences}

The basic science and mathematics courses are required for all students in the Clark School of Engineering, and provide a solid basis for the subsequent engineering courses that the students take. All of these fundamental courses are taken during the first two years of the student's curriculum.

A nuclear engineering student takes three calculus courses (MATH 140, MATH 141, and MATH 241) and a differential equations course (MATH 246) for a total of 15 credits. The student also takes three calculus-based physics courses (PHYS 161, PHYS 262, and 263), for a total of $1-1$ credits. A laboratory section is included with each of these courses. Finally, the student is required to take a minimum of one chemistry course. If a student enters the School with sufficient background in high school chemistry, he/she takes CHEM 133 (4 credits). A student who does not have the high school background takes a two semester sequence - CHEM 103 and CHEM 133 (8 credits). The chemistry courses include a laboratory. The Clark School of Engineering has established committees to continuously evaluate these course sequences. 
FIRST YEAR

ENES 100 - Introduction to Engineering Design

MATH 140, 141 - Calculus I, II

CHEM 133 - Chemistry for Engineers

PHYS 161 - General Physics I

ENGL 101 - Introduction to Writing

ENES - Statistics

CORE

\begin{tabular}{|c|c|}
\hline $\begin{array}{l}\text { Semester I } \\
\text { Credit Hours }\end{array}$ & $\begin{array}{l}\text { Semester II } \\
\text { Credit Hours }\end{array}$ \\
\hline 3 & \\
\hline 4 & 4 \\
\hline 4 & \\
\hline 3 & 3 \\
\hline & $\begin{array}{l}2 \\
6\end{array}$ \\
\hline
\end{tabular}

$\overline{14} \quad \overline{15}$

\section{SECOND YEAR}

PHYS 262, 263 - General Physics II, III

MATH 241 - Calculus III

MATH 246 - Differential Equations

ENES 221 - Dynamics

ENES 230 - Introduction to Materials

ENES 232 - Thermodynamics (or equivalent)

ENNU 215 - Introduction to Nuclear Technology

CORE

\section{THIRD YEAR}

ENNU 450, 455 - Nuclear Reactor Engineering I, II ENNU 441, 442 - Nuclear Engineering Laboratory I, II MATH/SCI Elective

Technical Elective

Secondary Field Electives

ENMA 464 - Environmental Effects on Materials

ENGL 393 - Technical Writing

CORE

\section{FOURTH YEAR}

ENNU 480 - Core Design

ENNU 443 - Nuclear Engineering Laboratory III

ENNU 465 - Nuclear Reactor Systems Analysis

ENNU 485 - Nuclear Reactor Thermalhydraulics

ENNU 490 - Nuclear Fuel; and Power Management

ENNU 495 - Nuclear Engineering Design

Secondary Field Electives

Technical Elective

CORE

\begin{tabular}{|c|c|}
\hline $\begin{array}{l}\text { Semester I } \\
\text { Credit Hours }\end{array}$ & $\begin{array}{l}\text { Semester II } \\
\text { Credit Hours }\end{array}$ \\
\hline$\overline{4}$ & 4 \\
\hline \multicolumn{2}{|l|}{4} \\
\hline \multirow{2}{*}{\multicolumn{2}{|c|}{3}} \\
\hline 3 & \\
\hline & 3 \\
\hline & 3 \\
\hline & 3 \\
\hline$\overline{14}$ & $\overline{16}$ \\
\hline Semester I & Semester II \\
\hline Credit Hours & Credit Hours \\
\hline 3 & 3 \\
\hline 1 & 1 \\
\hline 3 & 3 \\
\hline \multirow[t]{2}{*}{3} & 3 \\
\hline & 3 \\
\hline 3 & \\
\hline 3 & 3 \\
\hline$\overline{15}$ & $\overline{16}$ \\
\hline $\begin{array}{l}\text { Semester I } \\
\text { Credit Hours }\end{array}$ & $\begin{array}{l}\text { Semester II } \\
\text { Credit Hours }\end{array}$ \\
\hline 3 & \\
\hline 3 & \\
\hline & 3 \\
\hline & 3 \\
\hline 3 & $\begin{array}{l}3 \\
3\end{array}$ \\
\hline 3 & \\
\hline 3 & 3 \\
\hline 16 & $\overline{15}$ \\
\hline
\end{tabular}

Table 1. Nuclear Engineering Undergraduate Curriculum 
The nuclear engineering curriculum also includes a MATH/SCIENCE elective, which is in the student's third year. To fulfill this requirement, the student can choose any upper level (junior/senior) mathematics course, or any upper level science (chemistry or physics) course. The majority of the students select one of the MATH $46 \mathrm{X}(461,462$, 463,464 ) courses, which are advanced engineering mathematics courses taught by the mathematics department. MATH 461, Linear Algebra, is most often chosen. These courses include a computational aspect (Mathematica or Matlab) to provide the student with experience using modern tools to solve problems. Students have also chosen courses in the sciences, such as modern physics (PHYS 420) or Radiochemistry (CHEM 403).

\subsubsection{Engineering Topics}

The engineering topics contained in the nuclear engineering curriculum can be separated into a number of different areas:

\section{Basic Engineering Sciences}

Students are required to take four 'engineering science' courses. These are: Introduction to Engineering Design (ENES 100), which is a design- oriented course for incoming engineering students; Statistics (ENES 102) and Dynamics (ENES 221); and Introduction to Materials (ENES 230), which is a prerequisite course for a required Materials Engineering elective course taken in the junior/ senior year. Additionally, the student takes a course in engineering thermodynamics (such as mechanical engineering ENME 232 or chemical engineering ENCH 300 ).

The basic engineering science courses are taken in the student's first two years.

\section{Nuclear Engineering Courses}

\section{Required Courses}

The curriculum includes 27 credits of required nuclear engineering courses - eight three credit courses and three one credit laboratory courses. The courses are: ENNU 215 Introduction to Nuclear Technology; ENNU 450, 455 - Nuclear Reactor Engineering I, II; ENNU 441, 442, 443 - Nuclear Engineering Laboratory I, II, III; ENNU 465 Nuclear Reactor Systems Analysis; ENNU 490 - Fuel and Power Management; and ENNU 495 - Design in Nuclear Engineering.

Most courses contain both an engineering science and an engineering design component. Therefore, a student in the program gains design experience throughout the curriculum, which culminates in the capstone design course, ENNU 495. Courses with a strong emphasis on design include ENNU 455, ENNU 465, ENNU 480, ENNU 485, and ENNU 490. 
Safety and risk are discussed in these courses, with economic factors emphasized in ENNU 490. Ethics and societal impact are critical elements in the field of nuclear and radiation engineering and, as such, the student develops and understanding and appreciation of these issues throughout the curriculum. Engineering ethics is first introduced during the student's summer orientation program. Ethics is addressed again in the first engineering class, ENES 100, as well as during the required materials course, ENES 230. Ethical issues specific to nuclear and radiation technologies are discussed specifically in ENNU 215, 450, and 455. Discussions include handouts on current topics, both technical and societal. An additional advantage of this is impressing on the student the necessity of keeping current in his or her chosen engineering field.

All students are required to take the three-semester sequence of laboratory courses, ENNU 441, 442, and 443. As noted, the previous three-credit laboratory course in the curriculum, ENNU 440, was replaced with the three one-credit courses to allow a closer relationship between experiments and other course work. In these courses, the student learns about various techniques for radiation detection and measurement. The initial experiments focus on operations of standard nuclear electronics, various radiation detectors, such as GM tubes, scintillators, and solid state detectors, and introduce the concepts of the statistical nature of radioactive decay. Other radiation measurement experiments include measurement of isotope half-life, characteristics of shielding materials, gamma spectroscopy and identification of unknown isotopes, and subcritical multiplication and approach to critical (using the Maryland University Training Reactor). The students also use the Linac for experiments on dose deposition and the Co-60 source to examine energy tapping in crystalline materials.

All experiments require the student to write technical reports, in which he/she presents an analysis of the experiment, including theory, procedure, and results and analysis.

Students utilize computer application software, mainly word processing and spreadsheet, for preparation of these reports. In addition to the written report, it is typical that students make an oral presentation of results for one experiment.

An important aspect of the laboratory courses is that the student has the opportunity to design a significant part of the particular experiment. The student is provided with a brief overview of the experiment to be performed, and then it is his/her responsibility to develop a procedure, decide what data is to be obtained, and decide on the analysis methods required to meet the experimental objectives.

The laboratory courses also enhance the team building aspects of the curriculum. Students work in groups of, typically, two or three (depending on the availability of equipment) on each experiment.

The student's curriculum culminates in the capstone design course, ENNU 495 -Design in Nuclear Engineering. This course is the student's major design experience and is based on the knowledge and skills that he or she has obtained in previous coursework. The students work as a team (typically only one team, due to the small number of students) on an open-ended design project. Engineering concepts have been emphasized 
in the overall design project and, as much as feasible, other concerns, such as safety, environmental, and ethics/social/political are brought into the final design. The nature of the design problem, coupled with the number of students involved, limits the extent to which topics other than engineering can be brought into the project. In future years, however, somewhat technically simpler projects will be selected, which will allow more of the 'non-technical' issues to be addressed.

\section{Elective Courses}

Currently, two elective ENNU courses are taught on a regular basis. The first is ENNU 320 - Nuclear Reactor Operations. In this course, the student gains extensive hands-on experience with the operations of the Maryland University Training Reactor. The student learns about applicable federal regulations for licensed operations of this facility. Students write reports of experimental results. Additionally, this course enhances teamwork, as groups of approximately five to eight work on each experiment.

The second elective is ENNU 468E - Radiation Engineering. The course has been presented for two years, and we will submit the paperwork to obtain a permanent course number in the near future. Also, as mentioned previously, this course will be a required course in an upcoming curriculum revision.

The radiation engineering course provides the student with in-depth knowledge on uses of ionizing and non-ionizing radiation. Specifically, students are introduced to source technologies, absorbed dose measurements, interactions of electrons, photons, and neutrons in matter, and the design of radiation processing facilities.

\section{Secondary Field Courses}

Nuclear engineering students are required to select a secondary engineering field, which is a sequence of four upper level (junior/senior) courses in any other engineering discipline in the Clark School of Engineering. This secondary field choice allows the student significant flexibility in choosing his or her envisioned career path with the nuclear engineering degree. In the past, mechanical engineering was typically the most popular choice, with the student taking courses in the thermal sciences (advanced thermodynamics, fluid mechanics, power plant design, etc.). However, with the growth of non-power applications of nuclear and radiation technologies, fields such as materials engineering or chemical engineering are becoming the preferred secondary field.

The sequence of secondary field courses is discussed with and approved by the student's academic advisor, as well as the advisor in the secondary field. The secondary engineering field courses are required to contain both engineering sciences and engineering design, with the design component typically emphasized in the senior level courses.

4. Electives 
Three engineering/ technical electives are also required as part of the student's academic program. One of these electives must be a Materials Engineering course, ENMA 4xx. The student is advised not to take ENMA 464 - Environmental Effects on Engineering Materials but, if that course is not offered during the semester that the student wishes to take the ENMA elective, another ENMA course can be substituted, with the approval of the academic advisor.

If a student has chosen Materials Engineering as his secondary field, then an engineering elective, $\mathrm{ENxx}$, is substituted.

The other two electives can be either engineering courses or science/mathematics courses, depending on the student's overall curriculum plans. One or both of these courses can be in the student's primary or secondary field.

\subsubsection{General Education}

The general education requirements of the student's curriculum are satisfied with the University's CORE program. The CORE program builds a skill and knowledge base throughout the student's undergraduate career, and includes about $1 / 3$ of the total academic work required for graduation.

The CORE program has four major components. Fundamental Studies courses build student competence and confidence in basic writing and mathematics (the mathematics requirements are fulfilled with the required MATH courses in the curriculum). Students begin taking the Fundamental Studies courses, such as ENGL 101, in their first year.

The Distributed Studies courses allow the student to choose courses in broad areas in many disciplines. Students take courses in fields such as humanities, arts, history, and social sciences. These courses are typically taken during the first two years.

Advanced Studies courses provide the student with the opportunity to enhance his or her critical thinking skills, as well as his or her writing skills. All nuclear engineering students are required to take ENGL 393 - Technical Writing, as one of the Advanced Studies courses.

The final CORE component in Human Cultural Diversity, which encourages the student to learn about attitudes and cultures different from his or her own. Students can complete this requirement at any time in their curriculum, although it is typically done in the senior year.

When planning the CóRE courses, the student must also show depth as well as breadth. This is accomplished by selecting a sequence of at least two courses (one lower level and one upper level) in one area of social sciences or humanities. The sequence could be two courses from the same department, or courses that are related by a common theme. Therefore, the student gains more than an introductory level of knowledge in his or her chosen theme area. 


\section{Graduate Student Curriculum in Nuclear Engineering}

The graduate student curriculum in Nuclear Engineering has been accepted by the university's Program and Curriculum Committee (PCC) and is currently being phased in. It is structured in order to:

1. Strongly focus in the fundamental areas

2. Allowing students to enter with a broad range of different undergraduate degree programs, including all engineering disciplines, physics and chemistry

3. Building on the strength of the current faculty by defining three tracks of specialization:

- Nuclear Systems

- Radiation Engineering

- Safety and Reliability

A complete, self-contained description of this curriculum, including lists of contents for most of the courses, is attached.

\section{Professional Master of Engineering}

This program, which offers the Master of Engineering degree for the practicing engineer, has been developed by the engineering faculty of the A. James Clark School of Engineering at the University of Maryland College Park. It is an applications oriented, methods focused, part-time graduate program designed to assist engineers to the development of their professional careers and to provide the technical expertise needed in the business, government, and industrial environments. Late afternoon and evening classes are taught by the College Park faculty and experienced adjunct faculty at the College Park campus and designated learning centers in Maryland.

The Master of Engineering degree requires 30 credits of course work as opposed to the Master of Science degree that requires 24 credits of course work plus six credits of thesis (thesis option), or 30 credits of course work, a written comprehension examination, plus a scholarly paper (non-thesis option).

The professional Master of Engineering Program (ENPM) is open to qualified applicants holding a regionally accredited baccalaureate degree in engineering or a related field. In addition to submitting a Graduate School admission application, a copy of the applicant's college transcripts and; three letters of recommendation are required for evaluation. Applicants with an undergraduate GPA of less than 3.0 may be admitted on a provisional basis if they have demonstrated a satisfactory experience in another graduate program and/or their work experience has been salutary.

The student chooses an area of concentration offered by an engineering department and completes 30-credit hours of approved course work with an average grade of $B$. The course work, which allows up to 12 credits at the 400 -level, must be approved by the department's program faculty representative. 
Evening courses are offered on the College Park campus and a number of centers in Maryland. A number of courses originating from the College Park campus are taught on the Instructional Television Network (ITV), so that they may be taken at one of these centers or at a variety of ITV open sites distributed in Maryland.

\section{Professional Courses}

In order to provide government agencies and industries with focused continued education a set of professional courses in the area of radiation science and engineering have been developed covering different topics and time frames to comply with whatever needs exist.

\section{Role of Research in Curricula}

Research offers a challenge to the students to investigate and develop methods to:

- implement a team approach

- make decisions which affect the group

- acknowledge leadership by the person or organization most appropriate for a given function

- apply current technology effectively for communication and coordination

Experience in project integration offers students the opportunity to develop important workplace skills. The student team will experience issues which are common to the project as a whole and will establish communication channels and recommend problem solving techniques. The stidents will become aware of common issues through their own initiative, task updates and status reports. They will then lead development of solutions which certainly includes application of current communication technology.

Students' participations in meetings also establish a firm foundation for their professional networking skills with industry as a key basis for enhancing future competitiveness.

\section{Faculty}

The Nuclear Engineering faculty is small in size but well rounded in experience to meet Program objectives. Faculty experience covers all curricular areas of the Program, which translates very well to the students in the classroom. Teaching loads are typically two courses per semester, and all Program faculty are available to teach undergraduate program courses. The Program also offers M.S. and Ph.D. degrees, and all faculty are involved in research, which again enhances the undergraduate student's learning experience in the classroom. Research areas include radiation engineering, nuclear safety, nuclear system thermohydraulics, containment analysis, code development, and reliability and safety assessment. Through research and service work, the Program has ties to a number of government and private industries, including the US Department of 
Energy, US Nuclear Regulatory Commission, Baltimore Gas \& Electric, PECO Nuclear, NASA, Motorola, 3M, Johnson and Johnson, and NIST.

Faculty members encourage undergraduate student participation in ongoing research activities, internship programs, and professional summer job opportunities. Experience gained in these activities is an integral part of a student's engineering education.

The Program faculty perform extensive service activities by serving on Departmental, School of Engineering, and University committees. Each faculty member belongs to and participates in the activities of one or more professional engineering society. The faculty is also actively involved in Professional Development activities, by attending various professional society meetings, seminars, and workshops. 


\section{Center for Technology Risk Studies (CTRS)}

The Center for Technology Risk Studies (CTRS) was established in 1997 within the Department of Materials and Nuclear Engineering, University of Maryland. The CTRS provides a focal point within the University for research and education in risk assessment.

\section{Objectives}

The Center capitalizes on a long history of risk assessment and management capabilities at the University of Maryland, College Park. The overall objectives of the CTRS are:

1. To support Federal and state government agencies in risk assessment and riskinformed decision-making:

a) Risk analysis tools and techniques

b) Demonstration of application of methods

2. To provide a multi-disciplinary environment for research and education on technology risk.

The CTRS achieves these objectives by engaging in activities that include:

- Assessing risk of technologies

- Integration of tools, techniques and data for risk assessment and management

- Assessing risk-based implications of regulations

- Providing independent technical expertise and training.

\section{Rationale for the Center}

The Center for Technology Risk Studies provides a valuable resource of knowledgeable personnel that can provide: objective evaluations of risk assessment techniques, objective recommendations of approaches to meet risk assessment needs, and can develop new approaches or techniques to meet newly evolving needs in the risk assessment arena. Decisions must constantly be made by industry and governments, regarding the development and deployment of new technologies, and the management and/or disposal of the waste products from older technologies. Standardized methods and concentrated expertise are required to help make these decisions.

Federal and state governments are mandating that risk assessment tools be used more effectively in the establishment of new regulations so as to achieve a substantial degree of consistency. States which are relatively unsophisticated in the use of risk assessment methods, will surely have a need for assistance in applying such methods to a variety of situations, with some assurance that the decisions they make will be relatively consistent from one issue to another (with respect to risk) and from one state to another. Federal and State regulators and consumers raise issues about technology with respect to cost, overall societal benefits, and societal risks that might be imposed as a result of 
improper application, failure, or even normal use of the technology. Thus there exists constant pressure to improve the tools used in risk assessment and to make the results more consistent and acceptable to all parties affected or potentially affected by the risks. This Center has been established to meet these needs.

\section{Organization}

The organization of the CTRS is shown schematically in Figure 1 "Structure of the CTRS". The Co-directors of the CTRS, Professors Mohammed Modarres and Ali Mosleh, provide leadership for more than 20 faculty and research associates in the A.J. Clark School of Engineering, College of Business, and the Institute for Systems Research. These faculties are either active members or affiliates of the Center; they are listed in Table 1.

The activities of the CTRS are organized into three broad areas, each with several components, as follows:

1. Process systems

a) Energy (primarily nuclear)

b) Food Safety

c) Chemical Process

2. Transportation Systems

a) Space

b) Aviation

c) Land

3. Information Systems

a) Communications

b) Information Security

\section{Facilities}

The Center has two dedicated computing facilities equipped with 5 Sun and DEC ALPHA workstations and 15 top of the line PCs with a dedicated server. In addition, the computer laboratory of the Materials and Nuclear Engineering Department with 7 workstations is also available and used by the Center's students and researchers for their research and development activities.

Other laboratories for the study of physics of failure in electronics and optical components and devices are also available. The Fire Protection Department faculty who are also members of the Center maintain laboratories for fire hazard experiments. Finally, the thermal-hydraulics group operates the NRC-funded LOOP facility and maintains RELAP, CONTAIN, and several other advanced analysis codes. 


\section{Sponsors}

The CTRS has had the privilege to work with, either currently or in the recent past, the following sponsors:

* Nuclear Regulatory Commission (NRC)

- Department of Energy (DOE)

- National Aeronautics and Space Agency (NASA)

- Federal Aviation Administration (FAA)

* Food and Drug Administration (FDA)

* National Laboratories

$>$ Idaho National Engineering and Environmental Laboratory (INEEL)

$>$ Brookhaven National Laboratory (BNL)

$>$ Pacific Northwest Laboratory (PNL)

\section{Accomplishments}

Since its formation, the CTRS has made significant contributions to the state-of-the-art of risk assessment. In doing so, it has provided valuable assistance to its sponsors. Figure 2 "Examples Of Methods And Tools Developed By The CTRS" gives examples of computer codes and methods developed by the CTRS or its principals.

\section{Recent Activities}

Recent research activities at the CTRS include the following:

\section{Process Systems}

- TH-PRA Integrated Analysis for AP600

- Soviet-Designed Reactor Fire Risk Analysis and Training

- Decision Making Under Uncertainty

- Unified Risk and Performance Analysis Software

- NRC-UMD Cooperative Research on Risk-Informed Applications

- Farm-to-Table Process Risk Modeling and Assessment

- Characterization of Probabilistic Fracture Mechanics

- Fire Hazard Analysis

Transportation Systems

- Space Shuttle Risk Assessment

- National Airspace (NAS) Security Risk Management

- Coast Guard Risk Assessment Support Project

Information Systems

- Human Error Prevention in Telecommunication Systems

- Software Engineering Measures for Safety-Critical Digital Systems. 


\section{Contact Information}

\section{CTRS Address}

Marie Mount Hall, Rm. 2100J,

Department of Materials and Nuclear Engineering,

University of Maryland,

College Park,

MD 20742-7531, U.S.A.

Phone: (301) 405-5240

Fax:

(301) 314-9601

Co-directors

Prof. M. Modarres

E-mail: modarres@eng.umd.edu

Phone: (301) 405-5226

Prof. A. Mosleh

E-mail: Mosleh@eng.umd.edu

Phone: (301) 405-5215

\section{Staff}

Dr. Norman A. Eisenberg

E-mail: nae@bellatlantic.net

Direct Phone: (301) 384-6507 
Figure 1. STRUCTURE OF CTRS

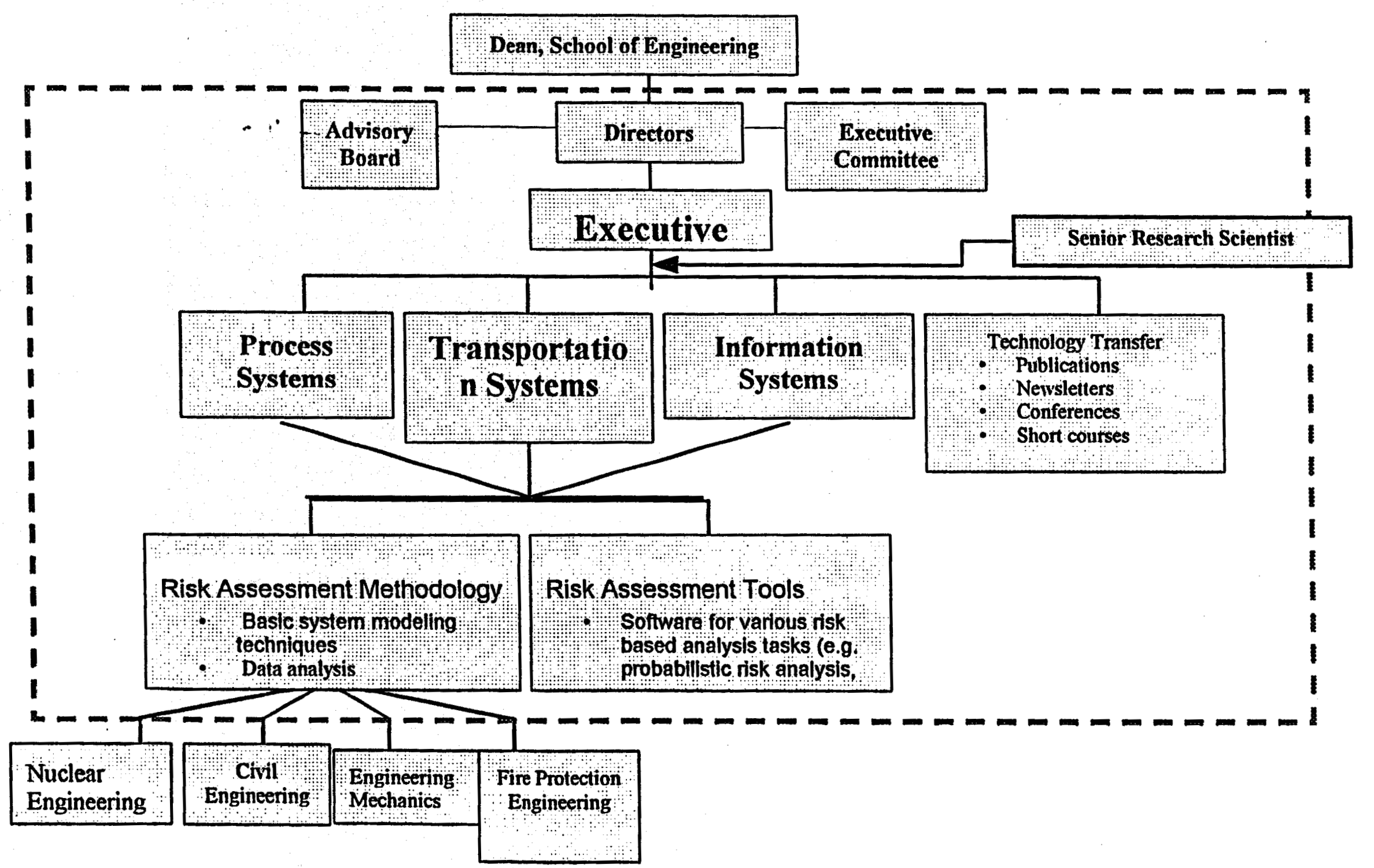


Table 1. More than 20 faculty and research associates in the A.J. Clark School of Engineering, College of Business, and the Institute of Systems Research are either active members or affiliates of the Center.

\begin{tabular}{|c|c|c|}
\hline Department & Name & Expertise \\
\hline $\begin{array}{l}\text { Materials \& } \\
\text { Nuclear }\end{array}$ & Dr. Christou, A. & Reliability Solid State Physics \\
\hline $\begin{array}{l}\text { Materials \& } \\
\text { Nuclear }\end{array}$ & Dr. Eisenberg, N. & $\begin{array}{l}\text { Performance Assessment, Risk Assessment, } \\
\text { Environmental Assessment }\end{array}$ \\
\hline $\begin{array}{l}\text { Materials \& } \\
\text { Nuclear }\end{array}$ & Dr. Modarres, $\mathrm{M}$. & Risk Assessment Methods, PRA \\
\hline $\begin{array}{l}\text { Materials \& } \\
\text { Nuclear }\end{array}$ & Dr. Mosleh, A. & $\begin{array}{l}\text { Data Analysis, Common Cause Failures, } \\
\text { Information Security }\end{array}$ \\
\hline \begin{tabular}{|l} 
Materials \& \\
Nuclear
\end{tabular} & Dr. Roush, $\mathrm{M}$. & $\begin{array}{l}\text { Human factors, Maintainability, Risk Assessment } \\
\text { Methods }\end{array}$ \\
\hline $\begin{array}{l}\text { Materials \& } \\
\text { Nuclear }\end{array}$ & Dr. Smidts, C. & Software Reliability, Dynamic Risk Assessment \\
\hline \begin{tabular}{|l} 
Materials \& \\
Nuclear
\end{tabular} & Dr. Al-Sheikly, M. & $\begin{array}{l}\text { Environmental Risk Analysis, Radiation } \\
\text { Engineering }\end{array}$ \\
\hline Civil & Dr. Ayyub, B. & $\begin{array}{l}\text { Structural Risk Assessment, Monte Carlo } \\
\text { Methods, Fuzzy Logic }\end{array}$ \\
\hline Civil & Dr. McCuen & Structural Risk Assessment \\
\hline Civil & Dr. Davis, A. & Environmental Engineering, Water Quality \\
\hline Civil & Dr. Torrents, A. & Environmental Engineering, Air Quality \\
\hline Fire Protection & Dr. Brannigan, V. & $\begin{array}{l}\text { Legal Issues, Risk Related Policy Issues, Risk- } \\
\text { Based Regulation }\end{array}$ \\
\hline Fire Protection & Dr. Milke, J. & Fire Propagation Modeling \\
\hline Fire Protection & Dr. Mowrer, F. & Fire Hazard Analysis \\
\hline Mechanical & Dr. Gupta, A. & Fracture Mechanics and Control \\
\hline Mechanical & Dr. Natishar, $M$. & Fracture Mechanics, Machinery Diagnosis \\
\hline Mechanical & Dr. Pecht, $\mathrm{M}$. & $\begin{array}{l}\text { Reliability of Mechanical and Electro-Mechanical } \\
\text { Systems }\end{array}$ \\
\hline Mechanical & Dr. Radermacher, $\mathbf{R}$. & $\begin{array}{l}\text { Environmental Friendly Energy Systems, } \\
\text { Alternate Refrigerants }\end{array}$ \\
\hline Electrical & Dr. Frey, J. & Reliability of High Power Microwave Devices \\
\hline Electrical & Dr. Fuja, T. & Error Detection and Correction Coding \\
\hline Electrical & Dr. Gligor, V. & Computer, Network and Information Security \\
\hline Electrical & Dr. Silio, C. & Computer Network Architecture and Reliability \\
\hline
\end{tabular}




\begin{tabular}{|l|l|l|}
\hline Chemical & Dr. Bentley, W. & Bioreactors and Biotechnology \\
\hline Chemical & Dr. McAvoy, T. & Process Control and Neural Networks \\
\hline Chemical & Dr. Calabrese, R. & $\begin{array}{l}\text { Accident Consequence Modeling, Environmental } \\
\text { Dispersion }\end{array}$ \\
\hline Geology & Dr. Tuttle, M. & Geological Evidence and History of Earthquakes \\
\hline Geology & Dr. Wylie, A. & $\begin{array}{l}\text { Geological Evidence, Uncertainty Calculations } \\
\text { for Natural Geological Phenomena }\end{array}$ \\
\hline Public Affairs & Dr. Schelling, T. & $\begin{array}{l}\text { Public Policy, and Risk Based Policy } \\
\text { Development }\end{array}$ \\
\hline
\end{tabular}




\section{Figure 2. EXAMPLES OF METHODS AND TOOLS DEVELOPED BY THE CTR}

\section{RISKASSESSMENT METHODOLOGY}

- System Logic Modeling (Functional Modeling, Goal Tree, Model Optimization)

- Risk Scenario Modeling (Dynamic, Discrete and Continuous Event Trees)

- Risk Model Integration (Computational techniques for large models)

- Human Reliability Methods (Cognitive models for qualitative and quantitative analy sis of human emor in risk scenarios)

- Data Analysis Methods (Particularly methods for analysis of probabilities of rare events, including use of partial evidenœ).

- Software Reliability Methods (Methods for assessing the level of reliability of software and corresponding error modes)

- Risk-Based performance monitoring methods for process plants

- Maintenance schedule optimization methods

- Hardware Reliability Methods

\section{RISK ASSESSMENT TOOLS}

Materials and Nuclear Engineering:

- ADS:

Accident Dynamic Simulator for Dynamic PRA of Nuclear Power Plant

- CCF:

Common Cause Failure Data (and CCDAT) Modeling Tool

- FRA:

Fire Risk Assessment

- MEMORES.

Maintenance Effectiveness Monitoring System, Maintenance Data-Base, and Maintenance Scheduling

- OSES:

Real-time operation support and operating procedure implementation and testing.

- ReDCAS: Data Collection and Analysis Software

- RCEXPERT: An expert system to perform root-cause failure analysis of complex systems

- RSAS: Expert systems for emergency response

- QRAS: Quantitative Risk Assessment System for Space Systems.

CE or Fire Protection

- RCSLIDE: Reliability of Gravity Structures

- STAR: Reliability of Assessment of Structures

- VBUSA: Reliability of Ship Structures 


\title{
APPENDIX
}

\author{
Radiation Facilities
}

\section{UM 2x4 Thermo-Hydraulic Loop}




\section{Radiation Facilities}

\section{Electron Test Facility}

The LINAC can produce micro-second pulses with peak currents up to $500 \mathrm{~mA}$, with electron energies up to $9 \mathrm{MeV}$. It can be operated in a single pulse mode or it can deliver a continuous train of pulses up to $360 \mathrm{~Hz}$. Pulse radiolysis equipment is also available for optical measurements of radiation induced transient species which absorb in the wave-length region between 215 and $800 \mathrm{~nm}$. Radiation induced conductivity can be measured in single pulse or continuous mode. It can also be used in experiments to determine dose distributions in complex absorbers as well as long term effects on the electrical properties of semiconductor devices of the mechanical properties of plastics.

\section{Maryland University Training Reactor}

The University's neutron test facility is licensed to operate at $250 \mathrm{~kW}$. The modified TRIGA reactor, consists of $93,20 \%$ enriched, uranium fuel rods in rectangular array. Samples can be exposed to neutron and mixed fields at a number of experimental ports and positions. Small samples, up to 0.7 " $(1.9 \mathrm{~cm})$ diameter and 2" $(5 \mathrm{~cm})$ long, can be placed into a 6 " $(15 \mathrm{~cm})$ diameter tube that runs across the face of the core. Beam ports on both the east and west sides of the facility provide a way of transporting neutrons out of the shield for experimental applications.

\section{Gamma Test Facility}

The Gamma Test Facility consists of a 10,000 curie cobalt-60 source. The source consists of tem source pencil rods $\left(0.5^{\prime \prime}(1.27 \mathrm{~cm})\right.$ diameter and $12 "(30.5 \mathrm{~cm})$ long) in the form of a hollow cylinder with a $4.5^{\prime \prime}(11.4 \mathrm{~cm})$ pitch. The source is stored at the bottom of a $15 \mathrm{ft}$. $(4.5 \mathrm{~m})$ deep water filled well. Prior to use an 18 " $(46 \mathrm{~cm})$ thick solid steel door seals the $15 \mathrm{ft}$. $(4.5 \mathrm{~m}) \times 15 \mathrm{ft}$. (4.5 m) room and the source is raised into the room's center. Samples are placed in the vault at selected positions to receive specific dose rates. The system automatically lowers the source when a predetermined time limit is reached. Dosimetry is performed in accordance with NIST traceable standards. Currently, experiments include radiation damage to electrical components, beneficial modifications of plastics, synthesis of polymers, preservation of food, and sterilization of biomedical devices. 


\section{The UM 2x4 Loop}

The University of Maryland 2x4 Thermalhydraulic Loop (UM 2x4 Loop) is a scaled thermal-hydraulic experimental facility. The Babcock and Wilcox (B\&W) lowered-loop design pressurized water reactor (PWR) is the prototype for our scaled model (1/500 by volume, and about $1 / 5$ by characteristic lengths). The UMCP $2 \times 4$ Loop was initially build to investigate single- and two-phase natural circulation transients. A subsequent addition of coolant pumps does now expand the experimental capabilities into forced circulation transients. The UM $2 \times 4$ Loop is equipped with prototypical auxiliary system including secondary circulation and emergency injection. Plans for the construction of the UM $2 \times 4$ Loop were formulated in 1982. The experimental facility began generating data in 1985 . The UM 2x4 Loop has been involved in a series of programs including: Small Break LOCA Investigations (1985-1990), Cold Shutdown Conditions (1990-1991), Heating of Primary System Components (1992-1993). Since 1993, the UM 2x4 Loop has been used to acquire data for boron-mixing investigations.
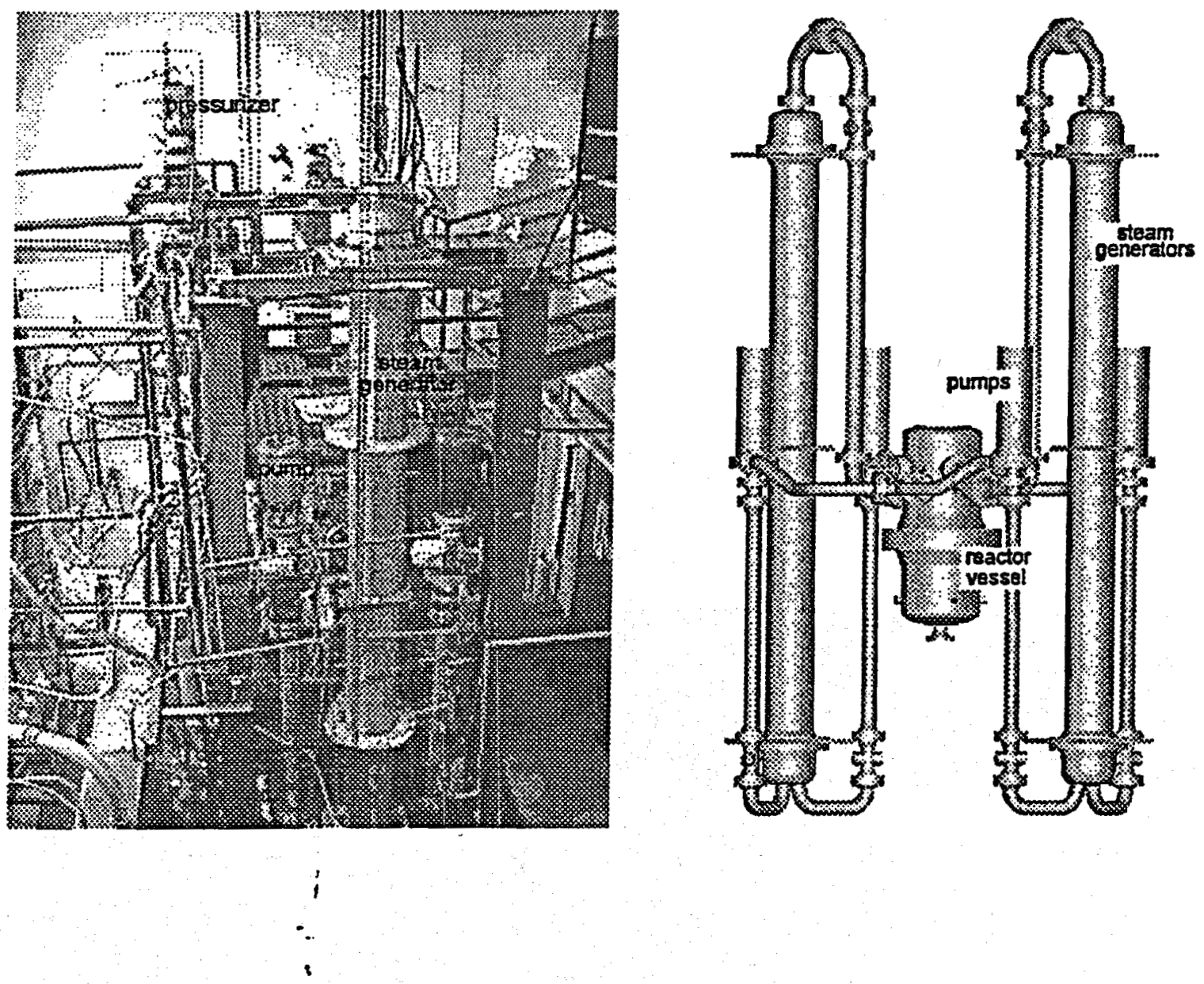


\section{The Visualization Facility}

The visualization facility was constructed as a scaled replica of the UM $2 \times 4$ Loop facility as a special effect facility. Only the components necessary to model the slug flow path are reproduced: the pump suction volume (or loop seal volume), the injection cold leg with its reactor coolant pump, and the reactor vessel. Additional components include a controlled-resistance bypass flow leg and a return flow path for the liquid leaving the reactor vessel. The entire reactor vessel and most of the attached pipes are made of transparent plexiglass. This allows the use of flow visualization techniques, such as Particle Image Velocimetry (PIV) and Laser Induced Fluorescence (LIF), to perform high-resolution measurements of the flow field and mixing phenomena. These methods offer several advantages over the traditional measurement techniques (e.g., thermocouples, conductivity probes), since they are non-intrusive and can achieve a much higher spatial and temporal resolution.

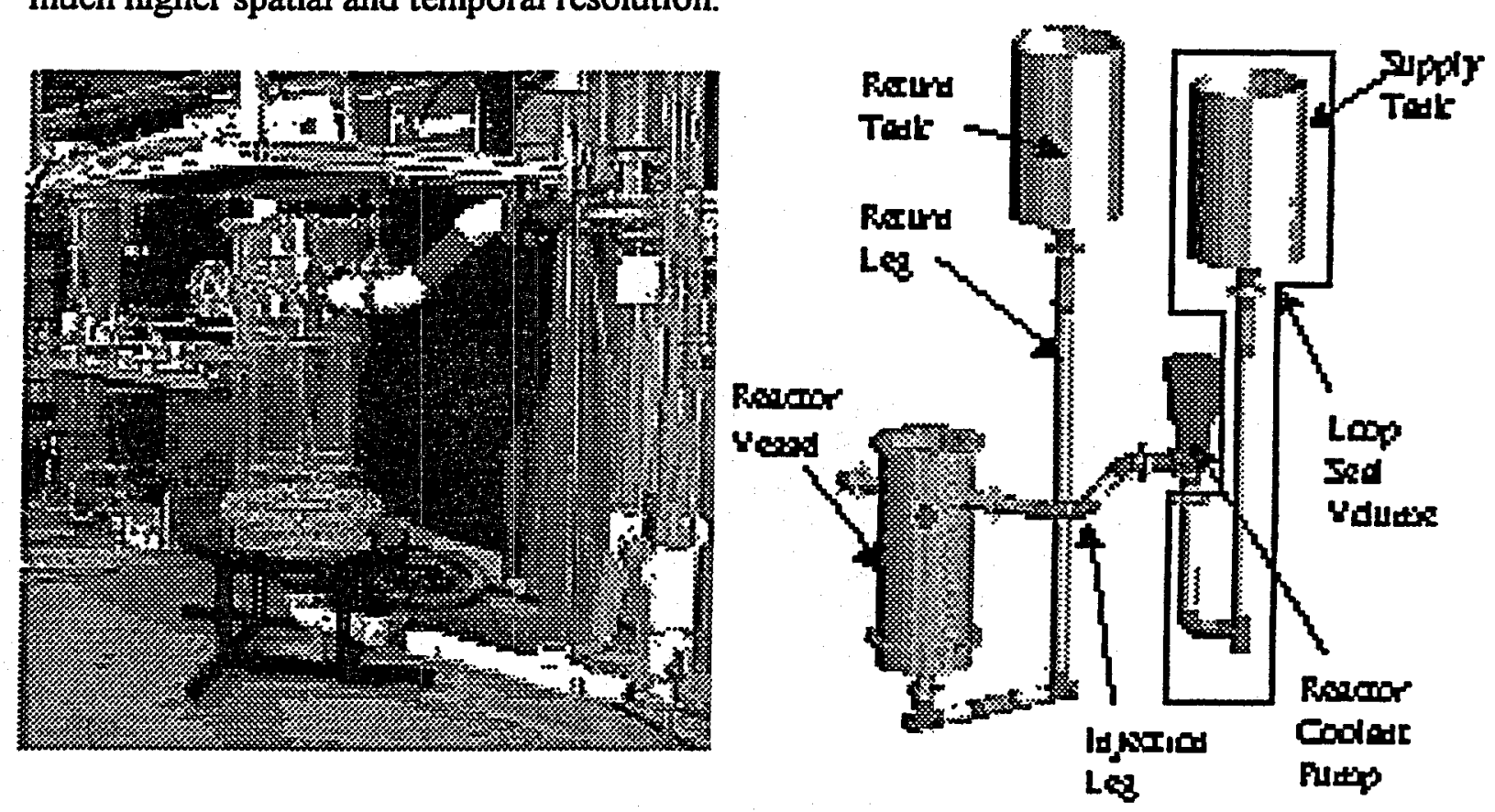




\section{RECENT PROGRAM ACHIEVEMENTS -}

- Application for Maryland UTR Licensing Renewal

- Graduate Program Review With Subsequent Change of Curriculum

- Full ABET 2000 Accreditation of the Undergraduate Program for Six Years

- Partner in U.S. DOE/Utility Nuclear Power Engineering Education Matching Grant Program With Baltimore Gas and Electric/Constellation Energy

- $3 \mathrm{M}$ Gift for Radiation Engineering

- International Standard Problem No. 43

- 2 Workshops at University of Maryland:

a) Determination of Optimum Radiolytic Treatment Methodologies for Remediation of PCB Contaminated Sites, Nov. 15-17, 1999

b) IAEA Consultants' Meeting: Post-irradiation Stability of Radiation Sterilized Medical Implants, Aug. 29-Sept. 1, 2000 


\section{RECENT STUDENT ACHIEVEMENTS -}

\section{Undergraduate Program}

- 3 ANS Scholarships (\$1000)

- 2 INPO Scholarships

- 2 Best Presentation Awards at ANS Student Conference

- Sophomore Class Average GPA above 3.75 with 2 Perfect GPAs

- 2 Student Summer Interns at U.S. NRC

- 1 Student Summer Intern at DOE

- Incoming Freshmen With Highest Average GPA and Highest Average SAT Scores in the School of Engineering

\section{Graduate Program}

- Dr. Joseph A. Green First Recipient of ANS Glenn T. Seaborg Congressional Science and Engineering Fellowship Serving in the Office of Rep.

Knollenberg

- Marc Garland Organized two Congressional Hearings on Capitol Hill

a) Nuclear Medicine

b) Future Energy Supplies (Focus on Foreign Affairs Article "Need for Nuclear Power" by Rhoades and Beller on behalf of the University of Maryland Chapter of the Eagle Alliance. He has a U.S. DOE Nuclear Engineering and Health Physics Fellowship. .

- Dr. Jason Floyd: National Research Council Associateship for 2 years at NIST

- Charles Greenwell: INPO Fellowship 